\title{
The Flapper in the Heterosexual Scene
}

\section{Liz Conor}

If it's naughty to rouge your lips, shake your shoulders, shake your hips

let a lady confess I wanna be bad.

This thing of being a good little girl is all very well

But what can you do when you're loaded with plenty of hell? ${ }^{1}$

These lyrics pose a rhetorical and somewhat risque question and in the 1920s they were provided with an emphatic answer: if a young Australian woman yearned to exhibit that she was 'loaded with plenty of hell' she should appear to be a 'Flapper'. In the 1920 s women began to appear in significantly different ways within the modern visual field, and by their presence they also constituted an aspect of its change. Types of 'Modern Woman', such as the 'City' or 'Business Girl', 'Screen Struck Girl' and 'Flapper' emerged within popular discourse which were not only classifiable 'at a glance' as it were, but were delineated by the new meanings that were accruing to women's public visibility.

More than any other type of Modern Woman, the Flapper embodied the sense of scandal which was attached to the new visibility of women in public, from women's increasing street presence to their being mechanically reproduced as spectacles. Modern women were spectacularised in the intensified visual scene of modernity, and these conditions constituted a new subject position for women what I will call the 'modern appearing woman'. This subject position was marked by a dramatic historical shift: women were invited to articulate themselves as modern subjects by constituting themselves as spectacles. Feminine subjectivity became increasingly performed within a visual register.

The newly emerged subject position of the Flapper was constituted through a play of looks. Like the other modern feminine types mentioned above, the Flapper complicated the picture of the Modern Woman by associating public presence and agency with her visibility. She went further than the others, though, by becoming a sexual subject through constituting herself as a spectacle and appearing in a heterosocial scene that was itself becoming increasingly informal by virtue of new leisure forms. In making a spectacle of herself, the Flapper seemed to court the gaze, specifically of men, and to assert her modernity as a sexual subject by paradoxically constituting herself as an object. She did so within the new conditions of feminine visibility brought about through the visually intensified scene of modernity, including its new conventions of anonymity and street visibility instituted in the perceptual relations between city dwellers; the invention, refinement and popularisation of new visual technologies such as cinema, industrialised image production and the increased use of photography in print media; and commodity culture and its use of the spectacle in display techniques. 
The Flapper was a favoured figure of mass cultural forms, particularly the cinema, and the depreciated value of 'low' culture and the industrially produced spectacle became associated with her. She was both indulged and made deviant by magazines which assumed a male readership, and she was at once the darling and the disdained of women's print media. Through her emancipated visual style she embodied the modern with its quest for recognisable feminine types. The Flapper was a type of the Modern Woman whose realm of action and descriptive possibilities were tied closely, though not exclusively, to the visual. The modern perceptual field was a field of enactment and performance in the self-fulfilment of the newly emerged subject position of the Flapper. The concepts of femininity as masquerade and gender as performance - 'a corporeal style, an "act", as it were, which is both intentional and performative, where "performative" suggests a dramatic and contingent construction of meaning' - are important here. ${ }^{2}$ While there were many facets to the Flapper, such as her mobility, love of dance and movement, and her 'sporting' sexual 'frankness' with men, this article will explore how she was constructed around perceptions of her visibility - how the meanings of her 'techniques of appearing', or the manner and means of execution of one's visual effects and status, were construed as part of the definitional parameters of this modern feminine type. The Flapper as a motif for the Australian heterosexual visual scene will be used to explore the new agency that was attached to modern women's spectacularisation and to ask why and how this was sexualised and scandalised while being sanctioned as heterosexual.

The term 'Flapper' originally meant 'a very young harlot' in the late nineteenth century. ${ }^{3}$ The Flapper has her etymology in the illicit commerce of a precociously deviant sexuality. She essentially remained a figure of young female heterosexuality, encompassing the spectrum of sexual trade, from the exchange of sex for 'treats' in the manner of the 'amateur' to the marriage market as entered by the society debutante. As a figure of scandal the Flapper contravened traditional understandings about the place of the feminine. She was not at home in the home. She sought out leisure and thrills rather than having any of the virtues of the hard-working Business Girl.

In an image which decorated sheet music distributed by Dinsdale of Melbourne with titles such as 'Oh How I Hate to Get Up in the Morning' and 'On the Level You're a Little Devil', the Flapper was an iconic figure of fun (if not a little phallic) being hotly pursued by two men in top hats and tails astride a bottle of 'bubbly'. Her desire for pleasure and for the heterosexual chase was deemed excessive, exemplified by her being 'obsessed by love of dress and gaiety', which would entrap her 'in the spider web of excitement'. The young Modern Woman who relished showing her jazz garters in public, ${ }^{4}$ flashed the 'glad eye' to strange men, found pleasure in breaking 'the social commandments' and set out to 'jazz a hectic course to perdition'. ${ }^{5}$ As she was single, she wanted more than the 'coming out' of the society debutante and a ritualised unveiling through rounds of social engagements. The Flapper diverted herself with the liberatory pleasures available to the young unmarried woman in an increasingly informal, commodified, leisure scene.

She pursued consumption as an activity and a site of self-description, borrowing the masculine modern imperative of self-definition — but whereas men 
invoked the realm of production, the Flapper took her meaning from the ostensibly passive and feminised realm of consumption. Captivated by the commodity spectacle, the Flapper roused all the ambivalences felt about the female consumer, her 'perverse cravings' seen as symptomatic of modern decadence and 'an allconsuming primordial female desire'. ${ }^{6}$ She seemed to delight in the anonymity of the transitory crowd and sashayed through the streets of the metropolis gleeful with the opportunity for appearing in the midst of its visual promiscuity. As such she rejected the national mythology that associated rurality with authenticity. She utterly rejected the lingering entanglements of morality surrounding the ideal of the decorous, modest and discreet young woman, choosing instead to pursue pleasure ostentatiously, thus becoming a figure targeted by 'Mrs. Grundy" ${ }^{7}$ and the 'Wowser'. 8

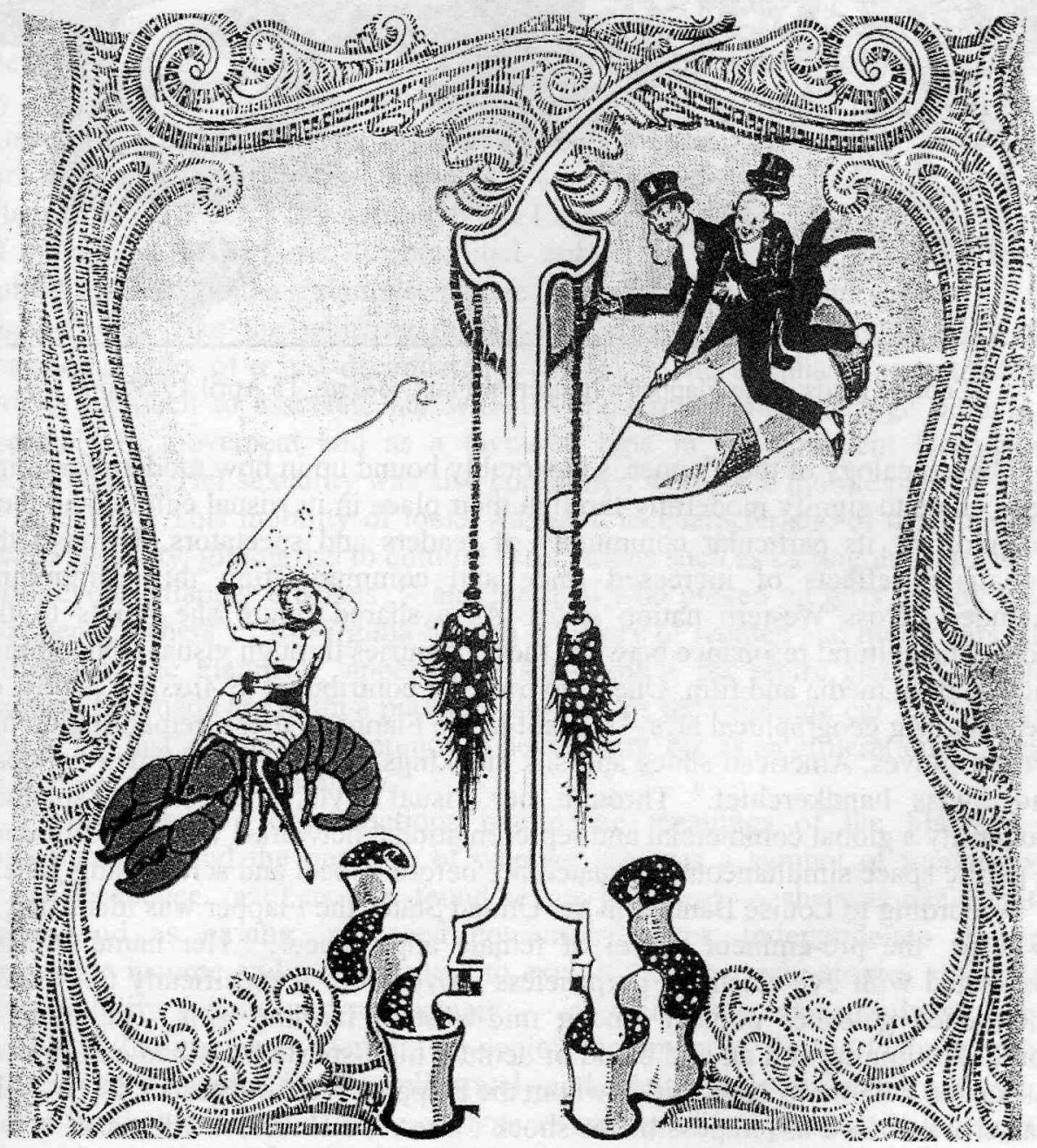

Cover image for Oh How I Hate to Get up in the Morning; On the Level You're a Devil but I'll Soon Make an Angel of You, Sheet Music produced by Chas A Wenman, both titles featured in a J C Williamson's theatre production Goody Two Shoes, 1919. The cast was photographed for Table Talk, 16 January 1919, pp 18-19 


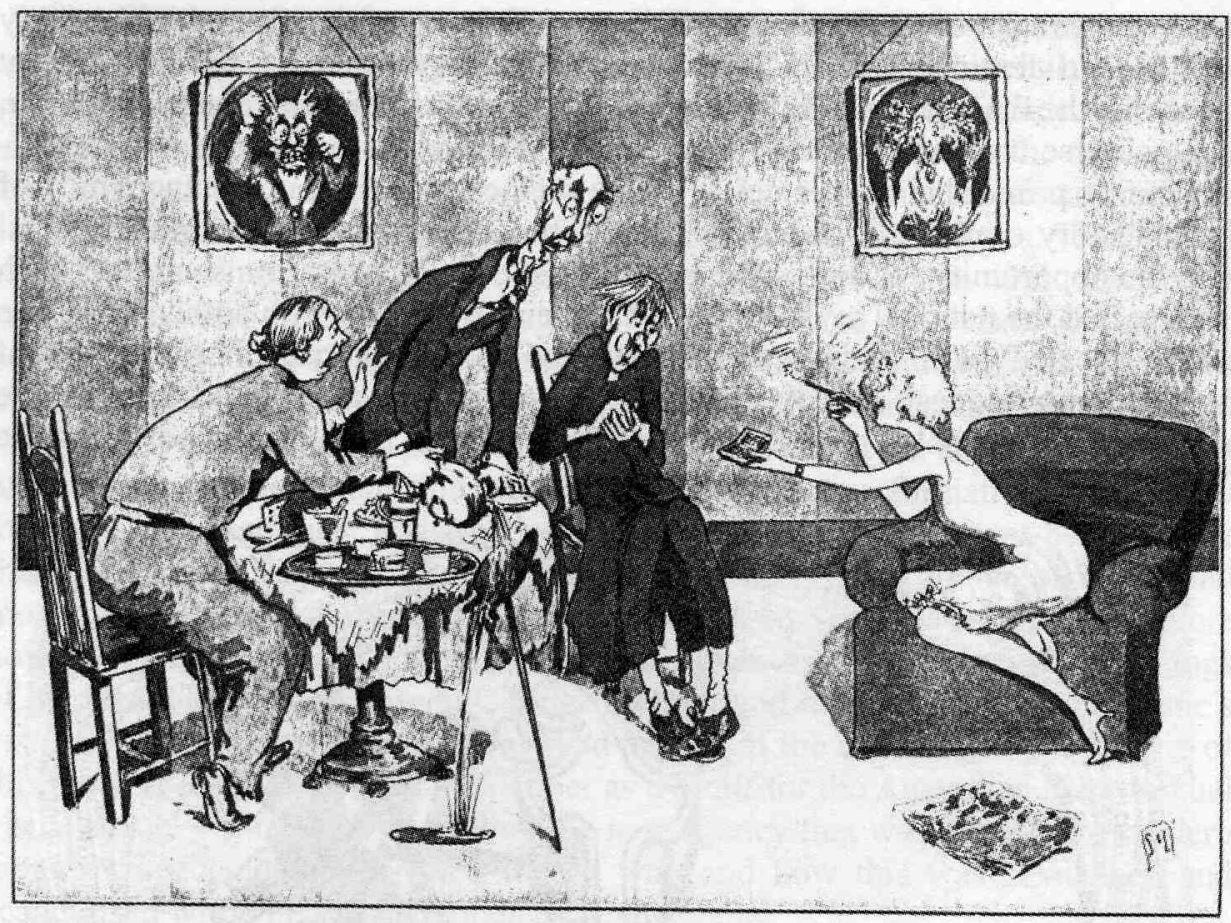

Caption reads: 'The Flapper's Indiscreet Flap', Aussie, 15 April 1929, p 8

The genealogy of the Flapper is inexorably bound up in how modern feminine types came to signify modernity through their place in its visual culture and their reception by its particular community of readers and spectators. Through the globalising effects of increased trade and communication this community extended across Western nation states. As a shared figure she points to the increasing cultural resonance between these countries through visual technologies such as print media and film. One tram traveller contributed to Aussie a 'study' of the 'amazing geographical array' evident in the Flapper's dress, remarking on her French gloves, American shoes and silk stockings, Italian hat, German handbag and Swiss handkerchief. ${ }^{9}$ Through her visual style, the Flapper spanned modernity's global commercial and representational networks, while her presence in public space simultaneously situated her before a local and scrutinising gaze.

According to Louise Banner, in the United States the Flapper was identified in 1913 as 'the pre-eminent model of female appearance'. ${ }^{10}$ Her name became associated with eye-catching, purposeless movement - specifically that of the unbuttoned galoshes popular among mid-western farming girls. The traits of youth, femininity, and an odd blend of demure high-spiritedness had earlier been associated with the Gibson Girl, ${ }^{11}$ whom the Flapper would succeed. ${ }^{12}$ In 1915 she was characterised as 'impossible to shock'. She read Havelock Ellis and, it was said, 'the world bears her no aspect of mystery'.13 This quality of knowingness continued to mark the deep ambivalence towards the Flapper: on the one hand she stood for modernity's quest for truth, but on the other hand she represented sexual agency. What might Flappers do with their knowledge? Communities looked to 
their techniques of appearing in an attempt to ascertain what effect her modernity might have on traditional heterosexual rites.

Billie Melman situates the British Flapper as being distanced from her unpalatable past in the interim decade between 1918 when women over thirty were enfranchised and 1928, when younger women won 'the flapper vote'.14 During this period Melman identifies a public obsession with feminine sexuality, one which would manifest in the definition of the Flapper. Her capacity to haunt the popular imagination in Britain also found impetus in the 'surplus woman' debate that occurred after the massive loss of young men's lives during the first world war and bred 'fears of a perturbed, demographically imbalanced society'. ${ }^{15}$

In Australia, these associations were adopted along with the type of the Flapper. She first appeared in the popular press as early as $1913 .{ }^{16}$ From his research into black and white drawings and low cultural forms over the turn-ofthe-century, Craig Judd has concluded that the term derived from the sounds made by loose shoes on the pavement, similar to the unbuttoned galoshes of the American farming girls. The British definition similarly derived from the young girl who had not yet 'come out' and whose hair, whether braided or hanging, 'flapped in the wind' ${ }^{17}$ By definition, the Flapper was deeply imbued with notions of movement, often loose, uncontrolled, erratic and situated outdoors or in the public eye. Bohemian columnist Dulcie Deamer wrote that the activity of the Flapper was 'like the whirring movements of a clockwork toy, or even the spasmodic jerks of a just-decapitated creature' ${ }^{18}$ This emphasis on movement would do much to associate her with the modern cinematic image both as a spectacle in movement and as a favoured type in the emergent Hollywood narrative film. Her sexuality was also configured within the mobile play of looks in modernity. This mobility of looks was seen as characteristic of the Flapper's sexual mobility, giving rise to cultural associations such as calling the side-car of motorcycles 'flapper brackets', ${ }^{19}$ and the men who picked up girls for joy rides 'flapper-snatchers' ${ }^{20}$ In Virginia Scharff's history of women and motor cars, she writes that the Flapper's 'appetite for self-display, for pretty clothes, and for reckless fun made her seem a perfect customer for the "pleasure car". ${ }^{21}$ She was said to be 'fast' not just in reference to her activity, but as an alliteration of visual movement and sexual mobility.

While there are contradictions within the meanings of the Flapper particularly around the question of whether she was a symbol of modernity's moral decadence, or of its new-found sexual frankness - she was consistently understood as having increased consumer power, independence through disposable income and a willingness to exploit the new technologies associated with mobility, leisure and amusement - of which she was mostly an adept handler. What is most evident in the copious commentary on the Flapper is that she was represented as having deliberately and calculatingly placed herself within a specifically heterosexual scene, with an awareness of and pleasure in the impact of her visual effects. Her childishness, joy rides, cocktails and visits to the 'flicks' created anxiety among her elders that sexual pleasure would become her favoured object and that her hedonistic immaturity would ultimately disqualify her from the traditional roles of maternity, marriage and domesticity. One commentator 
remarked that such young women found 'the bread and meat of marriage [a] poor substitute for the chocolates and flowers of courtship'. ${ }^{22}$

As a part of this anxiety, a regulatory system of discourses had begun to surround women's sexuality, which had given rise earlier to the 1903 NSW Royal Commission into the decline of the birthrate. In the 1920 s, the birthrate was half that of the $1880 \mathrm{~s},{ }^{23}$ a decline which was in part attributed to a 'love of luxury and social pleasures ${ }^{24}$ in young women. In Victoria in 1916, the government introduced an act to treat venereal disease, which defined young women, such as amateurs, as its source. ${ }^{25}$ The popularisation of Freudian psychology became part of this 'new network of knowledge' which surrounded the sexuality of young single women. ${ }^{26}$ 'Adolescence' and 'Flapper' were both late nineteenth century concepts, emerging together as popular knowledge, disciplinary effect and representational type, and overtaking earlier, less scientific notions of 'teenage' years as merely 'stressful'.${ }^{27}$ In 1922, the Home Budget wrote of Flappers between twelve and twenty years as 'in peril of nervous invalidism' due to their fears of adolescence. ${ }^{28}$ While the development of a healthy sexuality was essentialised in young women as 'a system as vital to health as any other bodily system', it was not, however, something to be flaunted. ${ }^{29}$

Katie Holmes suggests that the new meanings entering public life about the sexuality of young women had contradictory effects. In sexology, 'the female body became the repository of ideas not only about modernity but about sexual pleasure. Women were simultaneously objectified and rendered subjects of their own desire' ${ }^{30}$ In the 1920 s, young women appropriated the modern discourses of

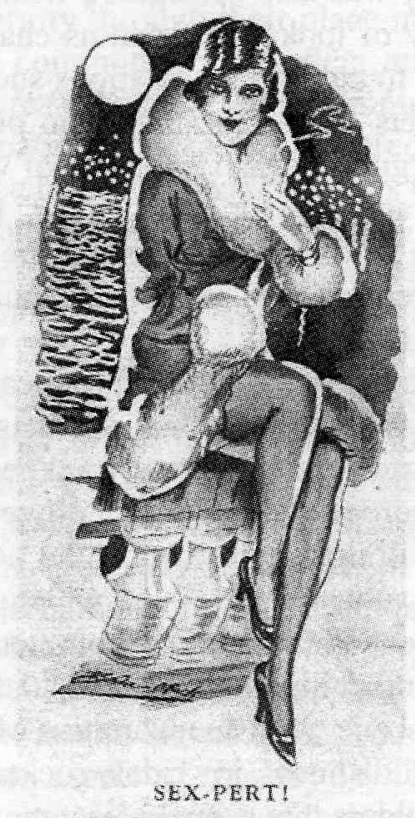

Caption reads: 'Sex-Pert', Beckett's Budget, 14 February 1930, p 1 
sexology into a knowingness of their own desire. Other, psychiatric and criminological, discourses at play brought into view the sexuality of modern young women. Young women seemed to work this discursive and representational web into a dangerous self-consciousness of the sexual effects of their visual desirability.

These young women - the 'sex-perts' - were in fact precocious experts in the prevailing understandings of both feminine sexuality and in the techniques of appearing through which they were sexualised. The public-isation of their sexuality intensified fascination with their visibility. Most often this fascination was focused on how young women situated themselves under the public eye through their techniques of appearing, and what could be known about their sexuality from these practices. As the public eye turned its attention to modern girls with renewed interest, their increased visibility was looked upon to signify their modernity.

The Flapper has been characterised as a trivial historical figure precisely because her visibility is emblematic of the way modern women made spectacles of themselves. A rift that was to last the century in western feminism emerged between the construction of feminine visibility as political participation, or as selfindulgent vanity. This dualistic perception precluded a recognition of the complex

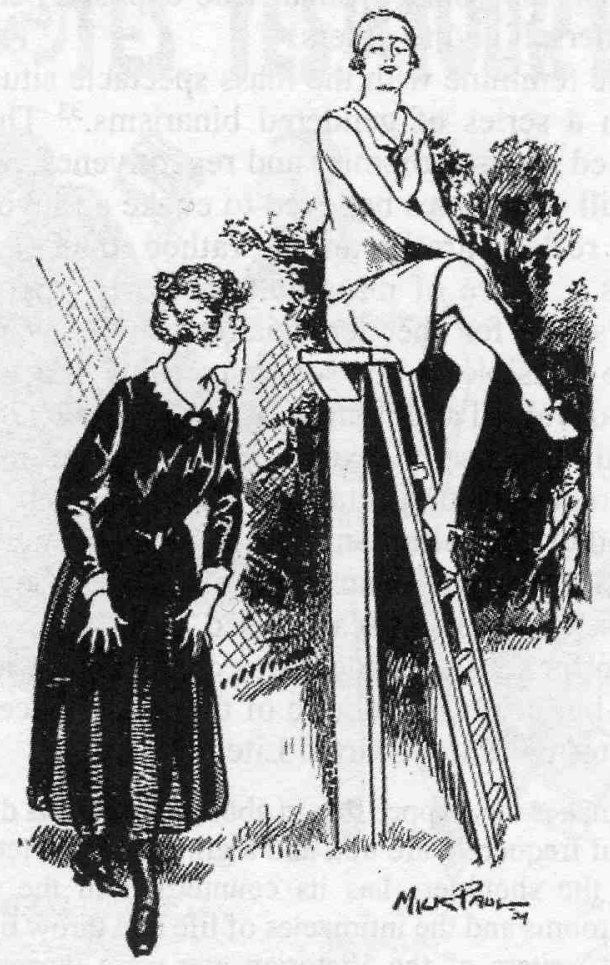

QUITE LEOTTIMATE.

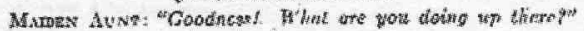

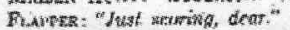

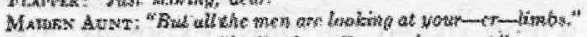

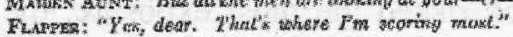

Caption reads: 'Quite Legitimate', Bulletin, 13 March 1929, p 41 
image of the Flapper, as asserting herself as a modern subject and a sexual subject through her object status.

Not surprisingly, older women at the time were often perceived as antagonistic to the Flapper. Feminists such as Vida Goldstein and Rose Scott singled out the Flapper as misusing women's hard won independence and newfound liberty on frivolous pursuits. ${ }^{31}$ Older women were represented as overly preoccupied with hem length and resentful of being eclipsed in the modern scene by the Flapper's attention seeking. Their resentment was construed as jealousy, which in turn was taken to express an outmoded sense of visual propriety. In one cartoon, a tram conductor chats amiably about the weather, remarking 'we could do with another three or four inches'. The Old Lady exclaims 'I should think so, indeed!'32

This flighty, dizzy young woman contradicted the knowing, self-assured Modern Girl, but both versions coexisted in definitions of the Flapper as projections of the twin anxieties that young women were both ill-prepared for the snares and lures of public intercourse, and yet all too prepared. Indeed, as selfconscious of their visual appeal and schooled through popular culture in the use of their wiles, young women were perceived as becoming the principal lures. Exposure was potentially a danger to young women against which they must vigilantly protect themselves. In the instance of the Flapper, the danger of exposure took a new twist: the young woman who exposed herself to the public was the danger, both to herself and to others.

The association of the feminine with the mass spectacle situated the feminine on the devalued side in a series of gendered binarisms. ${ }^{33}$ The mass-produced spectacle has been defined by its proximity and repetitiveness, its quantity rather than its quality. ${ }^{34}$ It is still sometimes believed to evoke an involuntary corporeal response, usually of reflex gratification, rather than appealing to the discriminating mind. As a figure of mass culture the Flapper, characterised as frivolous and shallow, stood for the depreciation of the visible as being too obvious compared to the invisible as 'the source of value, hidden from all but the enlightened few' ${ }^{35}$ The devalued and feminised mass spectacle entered the locale of the scandalous not only because of sexualised content, but more so through its mode of production as reproduced spectacle. ${ }^{36}$ When women, as the content of such imagery, were added to this cultural mix through the changes to visual culture in the 1920s, a kind of exposure was enacted on a number of levels. The feminine mass spectacle became sexualised and scandalised.

The Flapper's passion for self-adornment was characterised as an 'outlet to her unconscious urgings', ${ }^{37}$ but also as symbolic of the modern scene's tendency for exposure. 'Bookish' writes of 'Short Skirted Literature':

[T] he tendency which makes the flapper flap in abbreviated skirts displaying calves that may be shapely, but frequently are not, and a glimpse of garter, and in low cut transparencies around the shoulders has its counterpart in the modern novel's tendency to invade bedrooms and the intimacies of life and throw off all the clothes of life with which the writers of the Victorian age were wont to cover risqué situations. $^{38}$

As the modern type which risked the most exposure, the Flapper became a staple in comic puns and cartoons. Her vanity was written of as constituting a new 'fascinating' species, 'Shortskirtus Jazzgarterius', 'although it is immensely vain 
and over burdened with sensibility. Its passionate self-adornment is well known' ${ }^{39}$ Narcissism and exhibitionism were compatible with lingering perceptions of feminine deviancy. One columnist wrote that 'our streets and public places are filled with women who are apparently trying to see how much they can leave off without being arrested'. To these commentators, this fashion for exposure revealed nothing but 'some perverted sort of sex-impulse' ${ }^{40}$ Making a spectacle of oneself was condemned as 'flapper manners' and reviled. 'She powders her nose in public and shows her knees in trams or ferries because she thinks it is smart to do so. She combs her bobbed hair anywhere, in the theatre, in the street, in the office where she is employed' ${ }^{41}$ The transgressiveness of the Flapper's deliberate self-display was in her deployment of public space as her own personal exhibition space. As much as she was enthralled by mass spectacle, she was not prepared to enter the perceptual field as a mere spectator. She wanted to dominate the scene and control the anonymous play of looks within it.

The Flapper's calculated visual appeal was an indice to the morality of the Modern Girl. She was an opportunist in the changed conditions of feminine

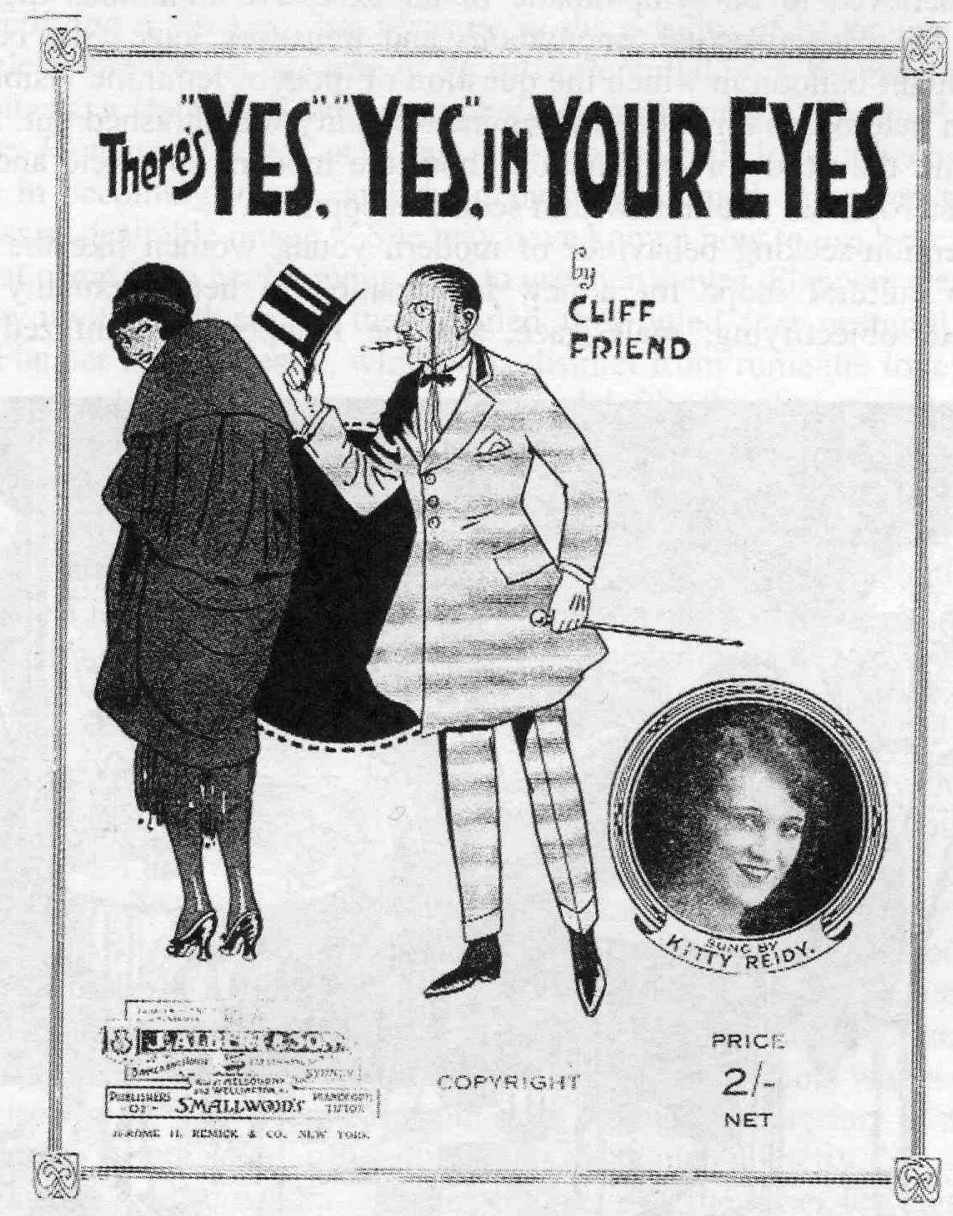

Caption reads: "There's "Yes", "Yes" in Your Eyes', Sheet Music, published by Jerome H Remick, New York and Detroit, Distributed by J Albert and Son in Sydney, 1924 
visibility, ever seeking eyes to bestow her with the pleasures of exhibitionism. Her desire to be seen was part of her precocious hankering to take the first steps on a sexual trajectory which was scandalous, if not deviant. By soliciting sexual attention from anonymous men, she took her place alongside the 'street Fairy', 'privateer' or 'amateur' 42 standing in the shadow of the street whore. Empowered by the invitations to look by mass culture, young women's gaze had acquired its own force. At the street level it sparked a network of mobile, gendered scopic encounters taking the colloquial form of the 'glad eye'. When young women 'cast' the glad eye at the 'gladsome eye' of 'mashers' ${ }^{43}$ their mobile looks were seen to signify their sexual mobility. 'Chase me clinahs' gave the 'glad eye promiscuously' and were said to be behind the persistent street harassment by 'masher's and 'knuts' who were forced to 'run the gauntlet of glad-eye girls' and yet were unfairly targeted by police as 'pirates of the street' ${ }^{44}$

The parameters of sexual activity seemed to extend during this period to include the play of looks between men and women on the street. The Flapper's mobile gaze was put to use in the soliciting of a desirous gaze. Her desire to be seen was believed to be symptomatic of an excessive libidinous urge to be objectified by a heterosexual, anonymous and transitory gaze. She became a cultural thought-balloon in which the question of modern feminine visibility and its effect on heterosexual rites and feminine sexuality was thrashed out. She was invested with the need for explanation about the modern spectacle and how it reframed heterosexual relations within scopic encounters.

The attention-seeking behaviour of modern young women like the Flapper gave much cultural scope for a new legitimation of heterosexuality and an essentialised, objectifying, male gaze, yet the Flapper was unfazed by the

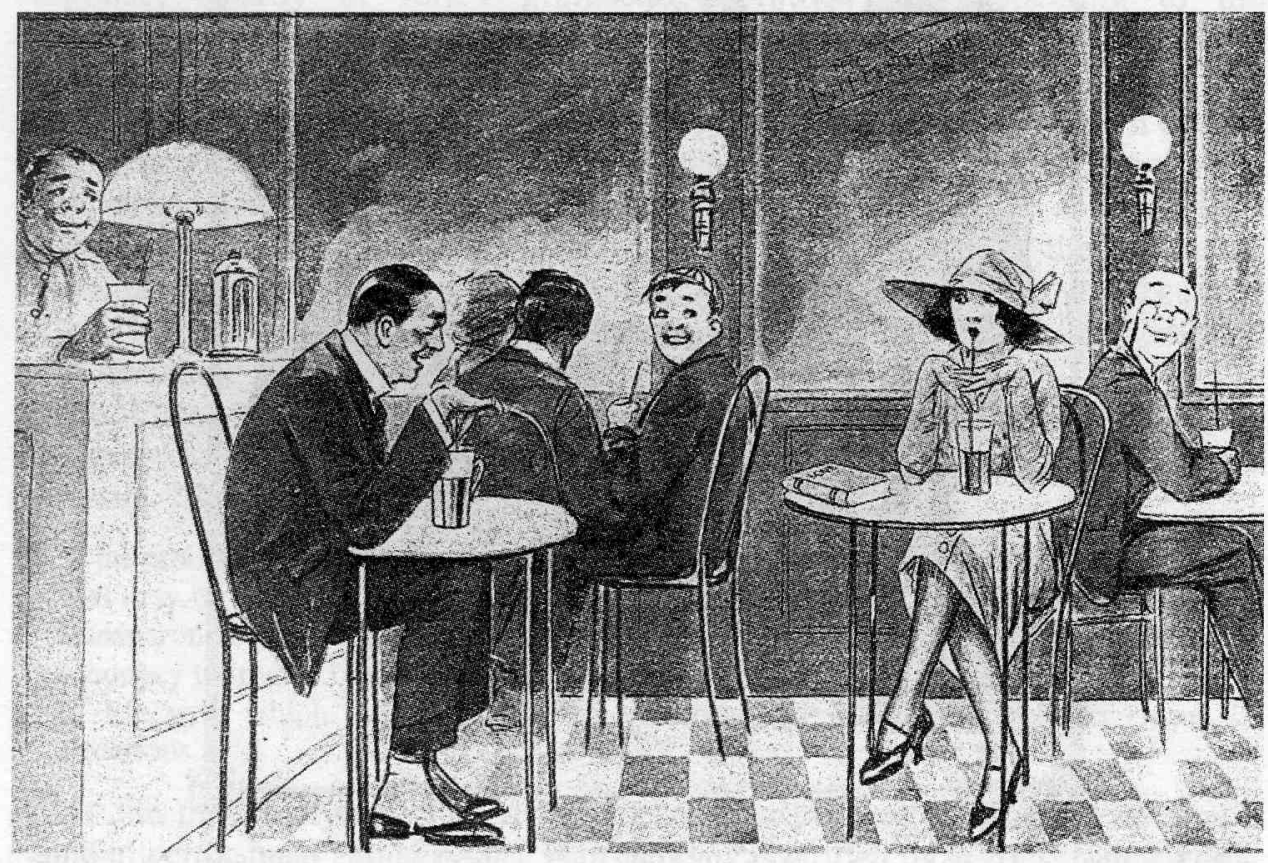

Caption reads: 'The Flapper's Wild Oats', Aussie, 14 July 1923, p 4 
attention; in fact she placed herself centre stage, and looked back expectantly, her initiative in such scopic encounters a feminised appropriation of 'wild oats' or sexual agency. In men's magazines, the Flapper became a particular point of fascination and her heterosexual desirability was often indulged, if not eulogised. The 'red hot flapper baby', 'must know just how to pet', read one ditty in the Mustard Pot. 45

In spite of being a 'gleeful sight', the dark side of the Flapper was never far removed. Men were warned:

Don't be a sap, don't fall in the trap

Be your age, my friend, be wise.

Though chic and pert, she's an awful flirt

And knows how to use her eyes. ${ }^{46}$

The Flapper's self-objectification was too calculated, too much elicited from men; they 'posture in a bathing suit/ Flaunting every angle' and 'Deck themselves like Sheba's queen/ 'Boyish' figures/ Spare and lean/ Ever syncopating' ${ }^{47}$ While constituting herself as spectacle seemed to invite and shore up the dominance of the objectifying male gaze, her pleasure in the activity of becoming image was nevertheless threatening because of its self-referentiality, self-consciousness and predatoriness: a Bathing Beauty was photographed under a 'Danger' sign in the Sun News-Pictorial. ${ }^{48}$ It was as though a responsive male look only confirmed her pleasure in becoming image, and the male gaze seemed entrapped by her selfawareness as desirable image. ${ }^{49}$ She may have known how to use her eyes, but her real threat came from her knowing how to use men's eyes. Flappers were 'not nice girls; they invited with smiles, they giggled, they ogled, they gestured'. ${ }^{50}$

The Flapper incited desire, which was distinct from romantic love, relegating her to the sexual arena of commerce and scandal. She thus became a useful figure in constructions of the culpability of deviant young women in sexual violence perpetrated by men. From 1919 to 1923 the Truth ran numerous accounts of allegations of incest, rape and indecent assault as the consequence of the 'worthless flapper's' deviant 'precocious proclivities'51 and her calculated visual appeal. The Flapper's resistance was 'very weak. She only said stop it, which, under the circumstances amounted to almost encouragement to the youth to go on' ${ }^{52}$ In such cases, the Flapper's frankness did nothing to help her defence: 'in giving evidence, the girl related her story with an ease and unconcern which gave the impression that she had a first hand knowledge about worldly things much beyond her years'. ${ }^{53}$ This version of the Flapper was a 'menace to young men of the community', sometimes repeatedly alleging rape, carnal knowledge and indecent assault, her every attempt at redress through the courts further typing her as deviant and in need of 'rigorous control', ${ }^{54}$ mostly in industrial and convent homes. The number of acquitted men indicated the extent of sexual violence against women and their lack of criminal redress, and the thorough undermining of the young women, through the type of the Flapper, as credible witnesses. Courts were advised to be 'very sceptical about even the biggest certainty of any flapper when it comes to a question of identification and a man's liberty'. .5

The Flapper's attire was 'a constant challenge to the baser feelings of young men', ${ }^{56}$ who were more or less asked to abnegate responsibility for their sexual behaviour onto the effects of feminine spectacle. The modern scene 'confronted' 


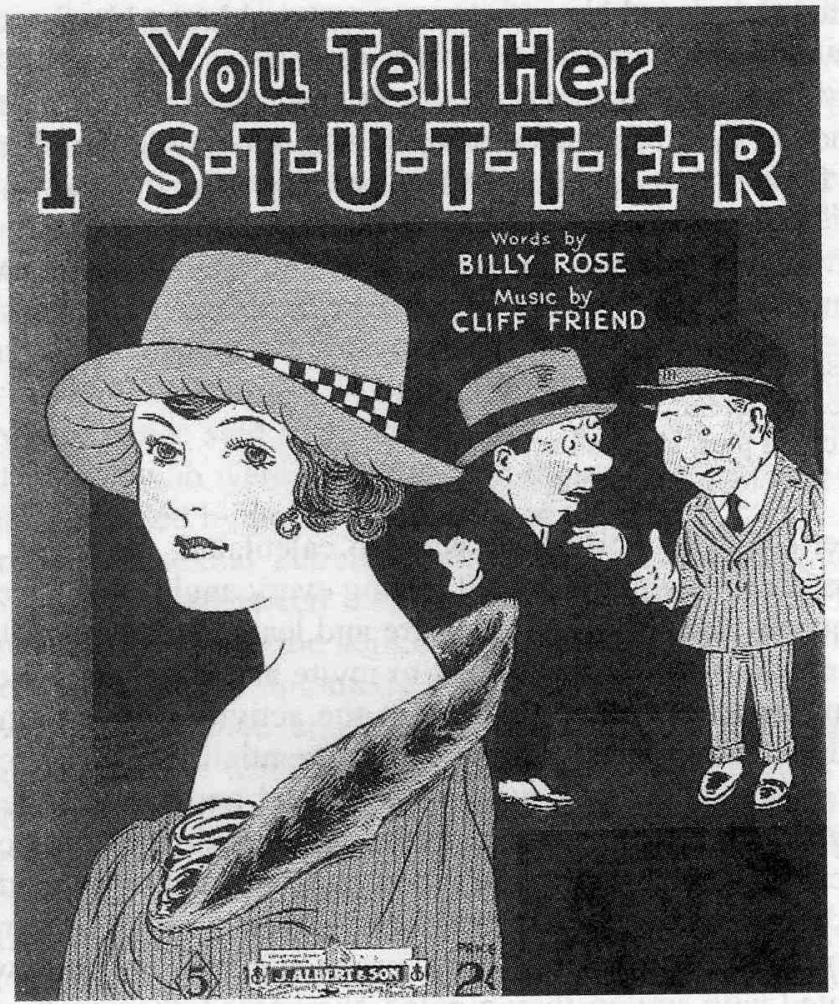

Caption reads: 'You Tell Her I S-T-U-T-T-E-R', distributed by J Albert and Son, Sydney and Melbourne, c.1922

young men with 'appeals to the senses' from every direction. They were overwhelmed by the public displays of shoulders: stuttering and gaping involuntarily. The 'countless exhibitions of intimate feminine attractions' was omnipresent - 'leg shows' in theatres, 'luscious pictures' from Hollywood, 'bedroom biographies' and 'half-naked bathing girls' pictured in 'aphrodisiac journalism' assailed the senses of men, making the modern scene part of a 'trying age,57 wherein feminine spectacle besieged from every side. The 'Flapper Trapper', in a somewhat unrequited scenario, loved men for the pleasures they could provide but did not identify pleasure in men themselves. They 'fooled and fleeced' men and vampirically 'cast them aside like sucked oranges', relying on abortionists ${ }^{58}$ and divorce courts to annul their 'natural' responsibility. The sexual contract was up-ended by the Flapper's predatory prowess - through being 'artistically hand painted' 59 - to take possession of men's desire, without allowing themselves to then be 'spoken for' in marriage. If she did marry, it was only as 'the one social novelty as yet unsampled'. ${ }^{60}$

The married Flapper posed a dilemma to the conventions of visual possession instituted by monogamous marriage. A woman's exposure had traditionally been accessed exclusively by her husband, whose gaze was private. The new public visibility of women posed transgressions of the conventional possession of women's sexuality. To see a woman's hair down, for instance, had been configured 
in literature and popular journalism as an erotic event through its associations with intimacy and sexual possession. ${ }^{61}$ As women bobbed their hair, moral disquiet turned around the fact that the discarded locks had once been the exclusive visual domain of their husbands. One literary critic described the domestic privilege of untied hair as 'virginal'. He lamented: '[t]heir intimacy has lost its crowning glory. They no longer awaken near a tousled lover, but instead, a friend with dishevelled hair', 62

The Flapper made publicly visible those aspects of femininity that only husbands should be privy to. Standing by an elevator, two Flappers astounded a staid gentlemen waiting nearby when discussing their underwear. One says, 'Oh, they're lovely' and her friend inquires, 'Have you got them on?' ${ }^{63}$ Young women were represented as prioritising their pleasure in appearing, even over the romantic and increasingly sexual adventure of marriage: 'I thought hubby objected to your wearing a bathing costume', a cartooned young man asks, gazing appreciatively at his acquaintance's figure. 'He did', she replies. 'What, [he] changed his view?' 'No, [I] changed my husband'. ${ }^{64}$ Marital duty, configured as visual fidelity to the exclusive view of husbands, was cast aside as young women's desire to appear to a variety of men took precedence. Engagement rings were said to 'put the dampener on some forms of amusements - perhaps because once glimpsed, the look over from men ended there. ${ }^{65}$

The agency that modern women were attaching to their techniques of appearing, the remonstrances of husbands about having to share their wives' charms with passing men, and the attempts to read women's sexuality from their visibility are all symptomatic of a dramatic shift in modern heterosexual relations - these relations were being ennacted at the level of the eye. In a mirroring of the bringing of sex into discourse, it seems women's techniques of appearing were brought into sex, that is, defined as sexual behaviour in themselves. Heterosexuality was becoming an activity of looking, so that John Berger's axiom 'men act, women appear' can be descriptive of not just the assignation of sexual difference through scopic relations, but the respective positions of men and women in heterosexual relations.

Despite this, the visual exposure of young women did not serve to reveal their truth, but rather girls 'who flagrantly and indelicately disport[ed] themselves on the crowded beaches', 'destroy[ed] the mystery of woman', itself a feminine 'truth' ${ }^{66}$ The Flapper provoked further fears of a loss of inscrutability of feminine essence in her adoption of artificial, standardised and reproduced images of women. A range of cosmetic products and techniques in 'beauty surgery' were reinventing the feminine as reproduced not just in terms of the mass-printed image but in the bodily transformations of self into a desirable image. Parrafin injections, hair dyes containing aphenylene diamine or lead acetate, removal of skin layers with acid, and associated risks of blood poisoning confirmed the scandalous lengths women might go to in their techniques of appearing in order to meet the ideals of fashion and youth. Such women were said to become 'uncanny' in expression, and acquire 'the face of something unnatural and inhuman' ${ }^{67}$ Her gregarious distortion of the natural self through artifice and sexualised display intensified anxieties about the reliability of visual evidence to accurately divulge the essence, let alone the moral categories of the feminine. 


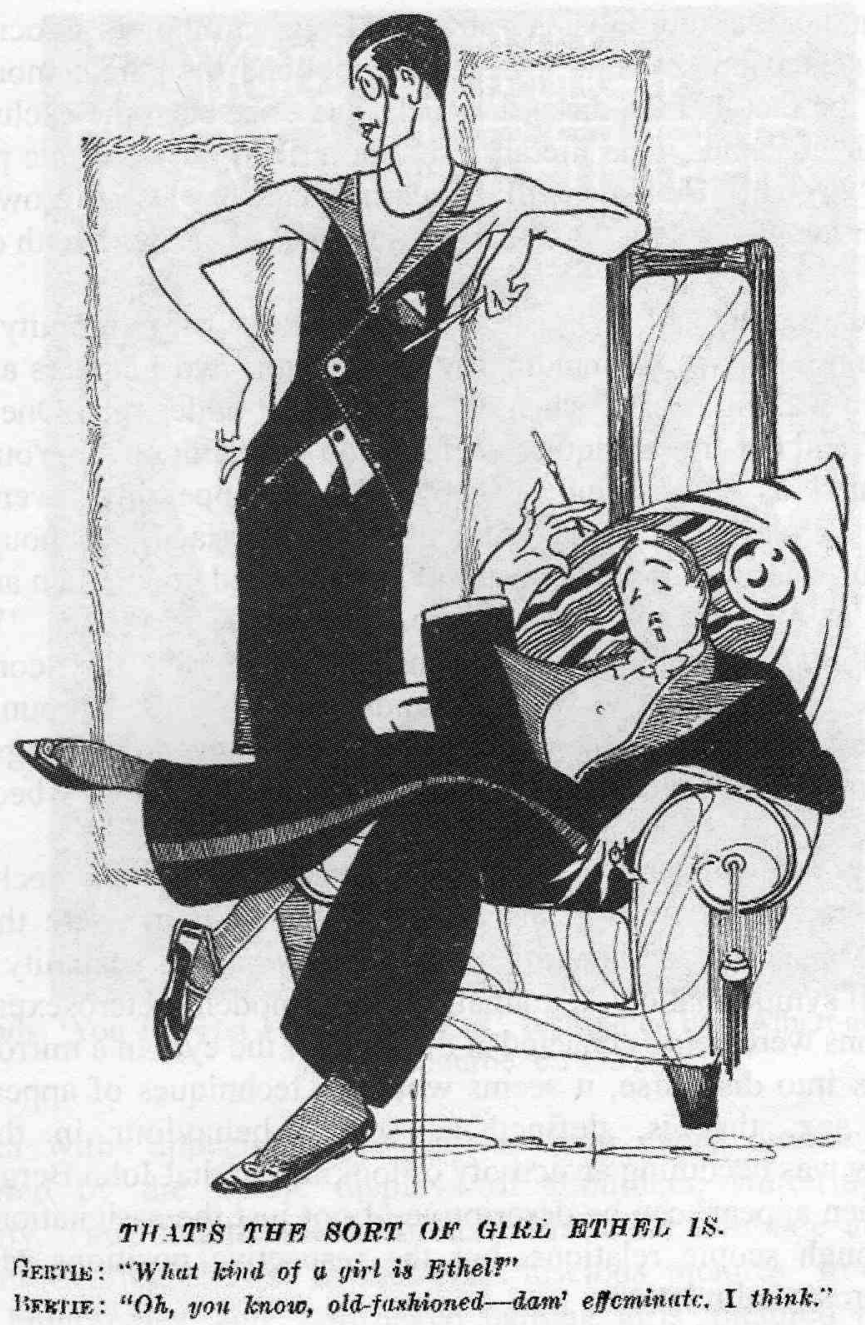

Caption reads: 'That's the Sort of Girl Ethel is', Bulletin, 19 May 1927, p 13

This loss of feminine essence was often represented as gender mutability or the diminishment of the particularity of modern young women's femininity through androgyny. In the 1920 s, the assumption of the look of gender indeterminacy was another cause for scandal. Margueritte's La Garçonne (1922) and Radclyffe Hall's The Well of Loneliness (1928) were banned, suggesting a focus in censorship on explicitness as well as lesbianism and gender transgression through visual ambivalence. This scrutiny would apply to the androgynous Flapper who was not adverse to the gender mobility of 'mannish' fashions. The boyishness of the Flapper was seen to be symptomatic of a rejection of the sexual responsibilities of maternity and womanhood proper. A Flapper's youth was not a shying away from heterosexual activity itself; rather it was a dangerous rejection of the social institutions in which it should be realised. Their gender mobility only seemed to 
serve to intensify the notion of her sexual mobility. Paradoxically, the Flapper's androgyny seemed only to heterosexualise her, because it was effected, like modern heterosexuality, at the level of the eye.

Barbara Cameron ${ }^{68}$ argues that the "new emphasis on glamour should not be seen solely as commercial exploitation, but rather as a move towards a new type of freedom' ${ }^{69}$ and that the new self-image of the Flapper 'answered a deep-seated need in women to assert their sexual identity' ${ }^{70}$ As feminine visibility became increasingly associated with cultural presence and self-mastery, the traditional scandal of the spectacle was won over by young women like the Flapper as they reclaimed spectacle as a site in the enactment of their modernity and their sexual agency. The Flapper responded to the spectacles of mass culture by seeing herself as a sexual subject, which she enacted through her quest for heterosexual objectification.

Within the wider modern tendency to bring sex into discourse, the Flapper vacillated in the popular imagination between representational form and a spectacularised feminine subject, each contributing to a construction of feminine sexuality that was enacted at the level of the eye. In both guises she was reproduced, either through visual technologies, or ostensibly through a too slavish devotion and mimicry of its conventions of feminine spectacle. In youth culture, she displaced the male gaze and yet also dominated its field of vision. She demonstrated that women who crossed cultural lines and altered or challenged their layout across the social field came in for particular surveillance, as objects of fascination and moral censure. If morality made a spectacle of itself, the Flapper seemed all too content to situate herself within dubious representational frameworks, and to play on the scandalous inferences of the industrially produced spectacle. She did so purely as a matter of pleasure in entrapping the attention of men, her scopic prey. Appearing as spectacle was scandalised because for women it became a sexual activity in itself.

When young women appeared as Flappers they toyed with the tension between cultural representation and subjective self-representation. They adopted the conventions of the mass reproduced feminine spectacle in their self-production through appearing, demonstrating that 'individuals are both the site and subjects of discursive struggle for their identity' ${ }^{71}$ The changed visual conditions for the realisation of this identity also meant that they broached the possibility that for modern appearing women 'visuality is the experience of Being becoming Representation'.72 
themselves and the self-interested muteness of the antagonists conspire to create a complicitous silence that is reflected in the historical record'. J C Scott, Resistance Without Protest, op. cit., p 422.

47 Gillian Cowlishw's Rednecks, Eggheads and Blackfellas is of extreme interest to the study of white Australia's representations of Aboriginal people. Her argument is that the differences between the 'redneck' pastoralists and the 'egghead' anthropologists projects were less significant than it is normally assumed, and that both groups were in fact incapable of developing an effective strategy to deal with Aboriginal strategies of outsiders management. See G Cowlishaw, Rednecks, Eggheads and Blackfellas: A Study of Racial Power and Intimacy in Australia, Allen and Unwin, Sydney 1999.

48 For a critical and comprehensive discussion of the nature of bias in nineteenth century sources relating to racial conflicts, see, J Belich, The New Zealand Wars and the Victorian Interpretation of Racial Conflict, Auckland University Press, Auckland, 1986, especially pp 311-335.

49 R Tonkinson, Aboriginal Victors of the Desert Crusade, op. cit.

50 ibid., p 143.

51 See for example, D May, Aboriginal Labour and the Cattle Industry, op. cit., pp 104-35, 184-5.

52 This concept is taken from H Goodall's Invasion to Embassy, op. cit., especially 'Part 1' and 'Part 2', and even more specifically, pp 57-72.

53 See, for example, H Reynolds, 'From Armband to Blindfold', the Australian's Review of Books, March 2001. Of course, observing that a debate is somewhat sterile does not imply maintaining that both the debating positions deserve and display the same degree of scholarly attention.

54 T Rowse, 'Indigenous Citizenship', op. cit., p 92.

55 R Evans, K Saunders and K Cronin, Race Relations in Colonial Queensland: A History of Exclusion, Exploitation and Extermination, University of Queensland Press, Brisbane, 1993, p xxxi.

56 B Attwood, 'Mabo, Australia and the end of History', in B Attwood (ed.), In the Age of Mabo: History, Aborigines and Australia, Allen and Unwin, Sydney, 1996, p 116.

57 N Wachtel, The Vision of the Vanquished: The Spanish Conquest of Peru Through Indian Eyes, Harvester Press, Hassocks, 1977, p 213.

\section{The Flapper in the Heterosexual Scene Liz Conor}

1 'I Wanna Be Bad', Helen and Kane, Victor R C A by De Sylva, Brown and Henderson, 1929.

2 See Judith Butler, Gender Trouble: Feminism and the Subversion of Identity, Routledge, New York, 1990, p 139.

3 Eric Partridge, A Dictionary of Historical Slang, Penguin Reference Books, Harmondsworth, $1972, \mathrm{p} 324$.

4 A letter from 'Sober Minded' in the Sun News-Pictorial about his disgust at having to look at a young woman's jazz garter on a tram from Melbourne to Camberwell sparked a column of letters about the visual scandal of young women. A typical response argued, "the present day woman is allowed too much rope in the way of immodest dressing - diaphanous blouses, muslin skirts, and silk stockings ... Nakedness is more pronounced each day, and if these bare-chested hussies are allowed to promenade in this fashion, heaven help the poor kids who gaze and wonder at what species they are living amongst'. See 'The Order of the Garter', Sun News-Pictorial, 6 January 1923, p 7, and 18 January 1923, p 19.

5 "I Hate Your Sex": Primrose Path to Perdition', Truth, 18 July 1925, p 12.

6 Rita Felski, The Gender of Modernity, Harvard University Press, Cambridge, Massachusetts, $1995, \mathrm{p} 79$.

7 'Grundy' was originally a character in a play by Thomas Morton, Speed the Plough (1798), 'whose name came to indicate a rigidly conventional moral propriety'. See the introduction by Sarah Wintle to Grant Allen's reprinted The Woman Who Did (1895), Oxford University Press, Oxford, 1995, p 2.

8 The Australian term 'wowser' was believed to have derived from a Mr Norton, an alderman of the Sydney City Council, who called an opponent 'the white-whiskered Wowser from Waverly'. Premier Jack Scadden was asked to expand the definition and answered with 'a person who made more fuss about a girl showing an inch of petticoat than about a dozen families living in poverty'. See the Truth, 26 October 1922, p 5. 
9 Sally Forth, 'The Flapper in the Tram', Aussie: The Flapper Edition, 15 April 1929, p 66.

10 Lois W Banner, American Beauty, Alfred A Knopf, New York, 1983, p 176.

11 The American Gibson Girl was created by Charles Dana Gibson who began to draw young women of uncanny prettiness, healthy stature and elegance who were spawned from the increasingly common appearance of beautiful young women in public space and were also said to realise America's independent and proud spirit. Gibson's drawings embodied a national feminine ideal from 1886 and throughout the 1890s. See Martha Banta, Imaging American Women, Columbia University Press, New York, 1987, pp 211-18.

12 The pictorial counterpart to F Scott Fitzgerald's literary creation of the Flapper in Daisy Buchanan was the American cartoonist John Held Jr whose images of party-going, car-petting Flappers frequented the cover of the American Life during the 1920s. The Flapper was said to be the Gibson Girl's rebellious daughter. She was personified in the United States by Anna Held, Eva Tanguay and the Florodora girls. See Banner, op. cit., p 201. Both types had been preceded and personified by Ava Willing Astor, the daughter of conservative New York society leader, Caroline Astor. When she played tennis with her friends wearing bloomers, Vogue magazine dubbed them 'the moderns'. See Banner, ibid., p 146.

13 H L Mencken, 'The Flapper', Smart Set, vol 45, no 2, 1915, pp 1-2. Cited in Janet Staiger, Bad Women: Regulating Sexuality in Early American Cinema, University of Minnesota Press, Minneapolis, 1995, p 2. My thanks to Julie Tisdale for this reference.

14 Billie Melman, Women and the Popular Imagination in the Twenties: Flappers and Nymphs, MacMillan Press, London, 1988, p 1.

15 ibid., p 16.

16 This date comes from Craig Judd's research into representations of sexuality in black and white drawing in turn-of-the-century Australia. See Joan Kerr, Heritage: The National Women's Art Book: 500 Works by 500 Australian Women Artists from Colonial Times to 1995, Craftsman, NSW, 1995, p 425.

17 Ruth Turner Wilcox, The Dictionary of Costume, Charles Schribner's Sons, New York, 1969, p 139.

18 Dulcie Deamer, 'The Flapper - Our Great Illusion', Beckett's Budget, 21 June 1927, p 11.

19 'The Lovers', Humour, 20 June 1924, p 14.

20 'Beware the Motor Prowler', Australian Woman's Mirror, 20 January 1925, p 11.

21 Virginia Scharff, Taking the Wheel: Women and the Coming of the Motor Age, University of New Mexico Press, Albuquerque, 1992, p 138.

22 Adam and Eve, 1 October 1926, p 8.

23 See Patricia Grimshaw, Marilyn Lake, Ann McGrath and Marian Quartly, Creating a Nation 1788-1990, Penguin Books, Ringwood, 1994, p 226.

24 ibid., p 194.

25 Julie Tisdale, 'Venereal Disease and the Policing of the Amateur in Melbourne during World War I', Lilith: A Feminist History Journal, no 9, 1996, p 43.

26 Catriona Elder, The Question of the Unmarried Woman: Meanings of Singleness in Australia in the 1930s, Masters thesis, Department of History, La Trobe University, Melbourne, 1992, $\mathrm{p} 20$.

27 Banner, op. cit., p 102.

28 'Frightened Flappers', Home Budget, 4 March 1922, p 9.

29 Elder, op. cit., p 24.

30 Katie Holmes, Spaces in Her Day: Australian Women's Diaries 1920s-1930s, Allen and Unwin, St Leonards NSW, 1995, p 93.

31 See Grimshaw, op. cit., p 239.

32 Cartoon in Aussie, 15 March 1927, p 51.

33 Traditionally, the feminine has been relegated to the side of the unauthentic, along with duplication and falsehood, while the authenticity of the original object has been attributed to the masculine. In this dichotomisation, material reality has been pitted against representation, as has fascination and seduction against critical reception. James Naremore and Patrick Brantlinger offer a critique of this assumption within philosophy, and show how it lent 'resistance to the serious study of visible cultural objects'. In James Naremore and Patrick Brantlinger, Modernity and Mass Culture, Indiana University Press, Bloomington, 1991, p 3.

34 The precedents in the scandal of the spectacle can be traced as far back as religious suspicions of 'concupiscentia ocularum', Augustine's ocular desire - the ability of the image to divert the 
mind from spiritual concerns. As discussed in Martin Jay, Downcast Eyes: The Denigration of Vision in Twentieth-Century Thought, University of California Press, Berkeley, 1994, p 13.

$35 \mathrm{Jim}$ Collins describes this response to mass culture. He argues: 'Making fascination antithetical to "critique" has been a stock in trade feature of avant-garde self-promotion since its inception; fascination has been made to mean uncritical acceptance, promiscuity, lack of rigour'. In 'Appropriating Like Krazy: From Pop Art to Meta-Pop', in Naremore, op. cit., p 212.

36 As Lynda Nead argues with regard to pornography, 'the material and cultural value of the pornographic is reduced by its reproducibility'. Lynda Nead, 'The Female Nude: Pornography, Art, Sexuality', in Lynne Segal and Mary McIntosh (eds), Sex Exposed: Sexuality and the Pornography Debate, Virago, London, 1992, p. 286. See also Jonathan Crary's discussion of the stereoscope, a popular visual device invented in 1849 that became increasingly associated with the pornographic, possibly causing its 'social demise as a mode of visual consumption'. The stereoscope took on the mantle of an indecent object because of its aptitude in visualising pornographic images. Jonathon Crary, Techniques of the Observer: On Vision and Modernity in the Nineteenth Century, MIT Press, Cambridge, Massachusetts, 1994, p 127.

37 Stage and Society, 1 November 1924, p 17.

38 'The Aussie Woman', Aussie, 15 March 1921, p 36.

39 'The New Zoology: The Flapper', Stage and Society, 15 December 1925, p 19.

40 'Wives and Mothers', Bulletin, 6 April 1922, p 7.

41 'Flapper Manners', Australian Woman's Mirror, 7 July 1925, p 39.

42 The 'amateur' was a transitional figure of feminine deviancy floating somewhere between the Flapper and the whore. Her commerce in sexual favours exchanged for treats, including 'joy rides', theatre tickets, cocktails and presents of fine clothes, was seen as being more dangerous than the direct monetary exchange of the whore because of the difficulty in identifying such women. They offered men 'a camouflaged respectability which society cannot penetrate'. They were held to be more responsible than the whore in spreading venereal disease, said to effect 10 per cent of Melbourne's population. This was the figure given by Dr James W Barrett in 'A Woman's Job', in Bulletin, 9 August 1923, p 11. The Flapper was situated in the cultural thoughtballoon which included types of modern young women who commercialised their sexuality in exchange for treats. The Flapper often appeared in Truth alongside these types who "were not professional prostitutes' and 'worked in offices and shops during the day, and seek the bright lights at night'. They were seen to be more dangerous in the spread of venereal disease by 'neglecting the precautions that the recognised "Scarlet Woman" knows are necessary to preserve her health', and because they could not be policed as their employers would vouch for them. See 'Tarts About Town: The Lure of the Bright Lights: Flirtatious Flappers, "Love Birds" and "Privateers", Truth, 29 March 1919, p 5.

43 'Masher' was a term also used in the United States, apparently adopted from the Gypsy verb 'to love'. Fan letters were called 'mash notes'. See Banner, op. cit., p 238.

44 'Mashers and Misses', Truth, 12 February 1921, p 5. In London, in 1922, a magistrate ruled that it was not a criminal offence to exchange approving glances, but that 'unwanted attention' could only be constituted by words. 'Is The Glad Eye Illegal?' Smith's Weekly, 18 November 1922, p
16 .

45 Another verse included 'She's got to throb with passion/ I want to hear her madly cry/ "Squeeze me, bite me, kiss me"'. In 'Cave Man Stuff', Mustard Pot, no 2, 'Red Pepper Issue', 1928, p 14.

46 By 'Ycleptos', 'The Flapper Pal', Aussie, 15 April 1929, p 15.

47 'Alec', 'The Eternal Flap', Aussie, 25 March 1929.

48 'At Last', Sun News-Pictorial, 3 November 1922, p 7.

49 The imbalance in population due to the deaths of men in the war prompted popular newspapers to speculate that 'surplus shes' were becoming more skilled and more overt in attracting men to marriage. Truth called it 'Playing a Man-Attracting Game', in 'Lovely Woman', Truth, 10 September 1921, p 5.

50 C G Hartley, 'The Myth of the Virtuous Sex', in Women, Children, Love and Marriage, London, Heath Cranton Ltd, 1924, p 8.

51 'Boy Mad: Worthless Flapper of Fifteen: Makes Awful Accusation Against Her Father', Truth, 23 June 1923, p 4. This Flapper was 'well-developed for her age' and cast 'a coquettish glance at her interrogator'. 
52 'Flapper Fun: Indecent Assault Charge', Truth, 12 December 1920, p 5; 'A Flapper's Frolics: Charge of Carnally Knowing', in Truth, 23 October 1920, p 5; 'A Wayward Wench: Fifteen Year Old Flapper's Fall', Truth, 29 May 1920, p 7.

53 'Mary's Misadventure: Country Flapper's Fall', Truth, 24 January 1920, p 9.

54 'Clara's Capers: Flighty Flapper's Frolic', Truth, 20 September 1919, p 5.

55 'Flappers' Charges: Some Who Gave Evidence Against Innocent Men', Beckett's Budget, 30 December 1927, p 11.

56 Comments of a barrister, G A Maxwell, in defending a client against charges of indecent conduct. Reported in 'Dress and Decency', Truth, 26 February 1921, p 5.

57 'Sex-Stuff and Crime', Bulletin, 18 July 1928, p 8.

58 Truth reported that the number of girls seeking such 'relief from shame' was 'legion', with 'the Women's Hospital treating 150 cases of septicaemia every week'. ' 150 Babies Murdered Every Week in Melbourne', Truth, 10 December 1927, p 1. See Janet McCalman, Sex and Suffering: Women's Health and a Women's Hospital: The Royal Women's Hospital Melbourne, 1856-1996, Melbourne University Press, Carlton, Victoria, 1998.

59 'Flapper - or Trapper of Men: New Type of Girlhood Invades Society - Hard, Cold and Selfish', Truth, 26 April 1924, p 9.

60 Dulcie Deamer, 'That Married Look', Australian Woman's Mirror, 7 September 1926, p 10. Deamer is again cynical about the Flapper. She continues, 'Marriage meant someone to be "wonderful" to them all the time, not just between tennis sets or in the home-going taxi someone to shoulder the small complexities that ruffle even the existence of a half-divine twentieth century flapper'.

61 A passage in a short story 'Theadora: a Fragment' is an instance. The narrator has just told Theadora she has beautiful hair: 'Not for any consideration in the world could I have restrained the irresistible desire to say the words, looking at her sitting sideways to me, noting the shining weight of her hair on the white neck, and that curious masculine shade upon the upper lip. A faint liquid smile came into her face. "Mine is not so long as that when you see it undone" she said, looking at me. "How long is it" I asked mechanically, turning over the leaves of the sketch book, and thinking in a crazy sort of way what I would not give to see her hair unloosed, and have the right to lift a single strand of it. "It would not touch the ground", she answered, "It must be about eight inches off it, I think". "A marvellous length for a European", I answered in a conventional tone, though it was a difficulty to summon it. Within my brain all the dizzy thoughts seemed reeling together till they left me hardly conscious of anything but an acute and painful sense of her proximity'. By Victoria Cross, in Elizabeth Showalter (ed.), Daughters of Decadence: Women Writers of the Fin-de-Siecle, Rutgers University Press, New Brunswick, 1993, p 26.

62 Cited in Mary Louise Roberts, 'Sampson and Delilah Revisited: The Politics of Women's Fashion in 1920s France', American Historical Review, vol 98, no 3, June 1993, p 673.

63 Aussie, 15 June 1922, p 14.

64 'All Right Now', cartoon in Bulletin, 19 May 1921, p 36.

65 'Should Men Wear Engagement Rings?' Adam and Eve, 1 December 1927, p 45. The article is more interested to ask this question of women.

66 'Surf Bathing and Your Complexion', Lone Hand, 25 October 1919, p 31.

67 Arnold Bennett, Our Women: Chapters on the Sex-Discord, London, Cansell and Company Ltd, $1920, \mathrm{p} 82$.

68 Barbara Cameron, 'The Flappers and the Feminists: A Study of Women's Emancipation in the 1920s', in Margaret Bevage, Margaret James and Carmel Shute (eds), Worth Her Salt: Women at Work in Australia, Hale and Iremonger, Sydney, 1982, p 257.

69 ibid., p 260.

70 ibid., p 262.

71 Chris Weedon, Feminist Practice and Poststructuralist Theory, Basil Blackwell, New York, 1987, p 97.

72 Norman Bryson, 'Tradition and Desire: From David to Delacroix', cited in Martin Jay, Downcast Eyes: The Denigration of Vision in Twentieth-Century Thought, University of California Press, Berkeley, 1994, p 105. 


\section{University Library}

\section{- M M I N E R VA A gateway to Melbourne's research publications}

Minerva Access is the Institutional Repository of The University of Melbourne

Author/s:

Conor, L

Title:

The flapper in the heterosexual scene

Date:

2002-01

Citation:

Conor, L. (2002). The flapper in the heterosexual scene. Journal of Australian Studies, 26 (72), pp.41-57. https://doi.org/10.1080/14443050209387737.

Publication Status:

Published

Persistent Link:

http://hdl.handle.net/11343/34426 